\title{
RISING TREND OF SEXUALLY TRANSMITTED INFECTIONS AMONGST THE PATIENTS ATTENDING THE DERMATOLOGY OPD, JNIMS, IN THE LAST FIVE YEARS (2011-2015)
}

\author{
Yumnam Lokendro', Ranjeeta Sapam², Julie Leishangthem³, Sarda Okram ${ }^{4}$ \\ ${ }^{1}$ Assistant Professor, Department of Dermatology, JNIMS, Imphal. \\ ${ }^{2}$ Associate Professor, Department of Dermatology, JNIMS, Imphal. \\ ${ }^{3}$ Senior Resident, Department of Dermatology, JNIMS, Imphal. \\ ${ }^{4}$ Senior Resident, Department of Dermatology, JNIMS, Imphal.
}

\section{ABSTRACT}

\section{BACKGROUND}

Sexually Transmitted Infections (STI) continue to be a present major health, social and economic problems in the developing world. The prevalence rates are far higher in the developing countries. This is a retrospective study done in Department of Dermatology at Jawaharlal Nehru Institute of Medical Sciences, Porompat, a large tertiary referral centre in Imphal, Manipur. Data of new patients who had presented to the STI Clinics from January $1^{\text {st }} 2011$ to December $31^{\text {st }} 2015$ were included in this study. Patients were categorised into syndromic diagnosis as per WHO classification. The age range of the patients mainly belonged to the 25 to 50 years' group. The Male-to-Female ratio of patients who presented to the clinic was 1:3.6. The commonest mode of presentation for female was vaginal/cervical discharge (81.7\%). The commonest mode of presentation for male was genital warts (41\%). HIV was detected in 8 patients.

\section{KEYWORDS}

STI, HIV, Vaginal Candidiasis, Trends.

HOW TO CITE THIS ARTICLE: Lokendro Y, Sapam R, Leishangthem J, et al. Rising trend of sexually transmitted infections amongst the patients attending the dermatology OPD, JNIMS, in the last five years (2011-2015). J. Evolution Med. Dent. Sci. 2016;5(73): 5338-5341, DOI: $10.14260 /$ jemds/2016/1211

\section{INTRODUCTION}

Sexually Transmitted Infections (STI) continue to be a significant major health, social and economic problem in the developing world. ${ }^{1}$ The prevalence rates seem to be much higher in the developing countries. ${ }^{2}$ Association of HIV and STI have been consistently reported.3,4,5 Developing countries usually lack the laboratory infrastructure required for diagnosis of STI. To overcome this, a syndrome based approach to the management of STI patients was developed by the World Health Organisation (WHO) and is being implemented in a number of developing countries. According to this syndromic approach, patients are categorised into various groups - those with urethral discharge, cervical discharge, painful scrotal swelling, vaginal discharge, genital ulcer - non-herpetic, genital ulcer - herpetic, lower abdominal pain and inguinal bubo. In this paper, we present our centre's experience and data of those patients who had attended our Sexually Transmitted Disease Clinic during the study period.

\section{MATERIAL AND METHODS}

This is a retrospective study done in Department of Dermatology at Jawaharlal Nehru Institute of Medical Sciences, Porompat, a large tertiary referral centre in Imphal, Manipur. Data of new patients who had presented to the STI Clinics from January $1^{\text {st }} 2011$ to December 31st 2015 were included in this study.

Financial or Other, Competing Interest: None.

Submission 19-08-2016, Peer Review 31-08-2016,

Acceptance 03-09-2016, Published 10-09-2016.

Corresponding Author:

Dr. Ranjeeta Sapam,

Moirangkhom Sougaijam,

Leirak, Imphal, India.

E-mail:ranssapam@gmail.com

DOI: $10.14260 /$ jemds/2016/1211
Patients were categorised into Syndromic Diagnosis as per WHO Classification: These include patients with vaginal/cervical discharge, urethral discharge, genital ulcersherpetic and non-herpetic, lower abdominal pain, inguinal bubo and scrotal swelling. Records of other manifestation like genital warts were also included in this study.

Detailed clinical history/sexual history and examination were done for all patients. Information pertaining to the type of contacts/frequencies/contacts with commercial sex workers/multiple sex partners was elucidated. HIV testing, RPR were done in all patients. For those presenting with discharge wet mount slide preparation, $\mathrm{KOH}$ slide preparation, gram staining and microscopic examination were done. Seropositive for both RPR (at one in eight dilutions) indicated the presence of active syphilis infection.

Gonorrhoea was diagnosed using a standard Gram stained smear of the discharge. Part of the discharge was also sent for culture sensitivity.

For HIV, double ELISA tests were done. Two positive ELISA test were considered positive for ELISA. Treatment were as per the pre-packed STI/RTI kits proposed under NACP III guidelines for syndromic management of STI/RTI and were provided by National Aids Control Organisation (NACO).

Counselling regarding the risk involved in unprotected sexual contact, vulnerability to acquire HIV infection in presence of other STIs, need for partner treatment and use of condoms were done by STI counsellor in all the patients.

\section{RESULTS}

\section{Socio-Demographic Profile}

Table 1 shows the rising trend in the overall STI infections amongst patients attending STI Clinic, JNIMS, from grand total of 332 patients in 2011 to 563 patients in 2015. Infected patients were predominantly female. 
The age range of the patients mainly belonged to the 25 to 50 years' group (Figure 1). The Male-to-Female ratio of patients who presented to the clinic was 1:3.6.

The commonest mode of presentation for female was vaginal/cervical discharge, which was noted in 1293 patients out of a total of $1582(81.7 \%)$. The commonest mode of presentation for male was genital warts and was seen in 180 patients (41\%).

The different mode of presentation in context to sex distribution is as depicted in Table 2.

A trend in increase in the incidence of vaginal discharge and genital warts has been found in the last 5 years. There is increase in the number of urethral discharge also. Vaginal discharge was noted in 220 patients in 2011, which went up to 387 patients in 2015 .

Herpetic as well as non-herpetic genital ulcer comprise only a minority of the patient at presentation. Such a presentation was more common in males, although it affected both sexes. Syphilis was diagnosed in 12 patients and was noted mostly in men, who practice sex with men (10/12). Ano-rectal discharge and inguinal bubo were rarely seen during the study period.

\section{Contact Tracing}

Majority of the source of infection in the case of female patients could be traced to their spouse and was noted in 364 patients. These life partners had contacts either with CSW or other sexual partners. These patients were often noted to have multiple sexual partners, $(186 / 2020)$ patients. Sexual contacts with CSWs were noted in 159 patients. Men having sex with men could be established in 16 patients only.

\section{Trends of STI Association with HIV \\ HIV was detected in 8 patients.}

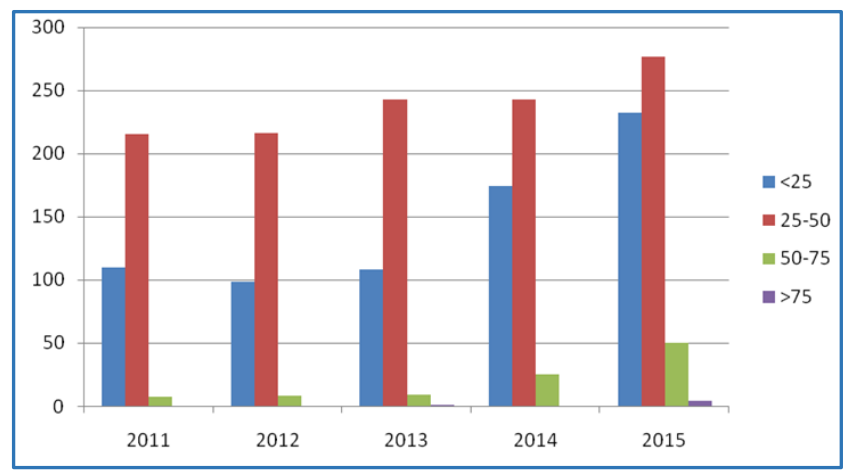

Fig. 1: Graph showing the Age Wise Distribution of the Affected Patients

\begin{tabular}{|c|c|c|c|c|c|c|c|c|c|c|c|c|c|c|}
\hline \multirow[t]{2}{*}{ Year } & \multirow{2}{*}{$\begin{array}{c}\text { VD } \\
\text { F }\end{array}$} & \multicolumn{2}{|c|}{ GUD-NH } & \multicolumn{2}{|c|}{ GUD-H } & \multirow{2}{*}{$\begin{array}{c}\text { LAP } \\
\text { F }\end{array}$} & \multirow{2}{*}{$\begin{array}{c}\text { UD } \\
\mathbf{M}\end{array}$} & \multirow{2}{*}{$\begin{array}{c}\text { ARD } \\
\text { M }\end{array}$} & \multirow{2}{*}{$\begin{array}{l}\text { IB } \\
\text { M }\end{array}$} & \multirow{2}{*}{$\begin{array}{l}\text { SS } \\
\text { M }\end{array}$} & \multicolumn{2}{|c|}{ Genital Wart } & \multicolumn{2}{|c|}{ Other STI } \\
\hline & & $\mathbf{M}$ & $\mathbf{F}$ & $\mathbf{M}$ & $\mathbf{F}$ & & & & & & $\mathbf{M}$ & $\mathbf{F}$ & $\mathbf{M}$ & $\mathbf{F}$ \\
\hline 2011 & 220 & 3 & 1 & 7 & 1 & 5 & 5 & 3 & 1 & 0 & 32 & 6 & 19 & 29 \\
\hline 2012 & 181 & 3 & 2 & 6 & 3 & 9 & 8 & 4 & 1 & 0 & 28 & 7 & 39 & 31 \\
\hline 2013 & 236 & 4 & 2 & 2 & 0 & 7 & 2 & 1 & 1 & 0 & 40 & 14 & 37 & 15 \\
\hline 2014 & 269 & 5 & 2 & 7 & 4 & 6 & 2 & 0 & 1 & 0 & 35 & 4 & 48 & 9 \\
\hline 2015 & 387 & 5 & 2 & 5 & 3 & 43 & 7 & 0 & 2 & 0 & 45 & 8 & 30 & 26 \\
\hline
\end{tabular}

M=Male, F=Female, VD: Vaginal Discharge; GUD-NH: Genital Ulcer-Non Herpetic; GUD-H: Genital Ulcer-Herpetic; LAP: Lower Abdominal Pain; UD: Urethral Discharge; ARD: Anorectal Discharge; IB: Inguinal Bubo; SS: Scrotal Swelling.

\begin{tabular}{|c|c|c|c|c|c|c|c|}
\hline Year & $\begin{array}{c}\text { Grand Total of } \\
\text { Patients } \\
\text { Attending OPD } \\
\text { Annually }\end{array}$ & $\begin{array}{c}\text { Grand Total of } \\
\text { STI Patients }\end{array}$ & Male & Female & $\begin{array}{c}\text { PLHAs among } \\
\text { the STI } \\
\text { Patients }\end{array}$ & $\begin{array}{c}\text { RPR Test } \\
\text { Reactive } \\
\text { among } \\
\text { the STI } \\
\text { Patients }\end{array}$ & $\begin{array}{c}\text { Grams' Stain } \\
\text { Positivity } \\
\text { among the } \\
\text { Discharge } \\
\text { Patient }\end{array}$ \\
\hline 2011 & 18805 & 332 & 70 & 262 & 0 & 0 & 4 \\
\hline 2012 & 28065 & 322 & 89 & 233 & 0 & 3 & 1 \\
\hline 2013 & 22079 & 361 & 87 & 274 & 0 & 2 & 0 \\
\hline 2014 & 31755 & 442 & 98 & 344 & 0 & 0 & 3 \\
\hline 2015 & 27283 & 563 & 94 & 469 & 0 & & 7 \\
\hline
\end{tabular}

\begin{tabular}{|c|c|c|c|c|c|c|}
\hline Year & MSM & IDU & CSW & Known Persons & Life Partner & Multiple Partners \\
\hline 2011 & 1 & 23 & 18 & 33 & 100 & 41 \\
\hline 2012 & 0 & 10 & 20 & 33 & 59 & 30 \\
\hline 2013 & 6 & 2 & 24 & 46 & 60 & 38 \\
\hline 2014 & 4 & 0 & 46 & 34 & 66 & 47 \\
\hline 2015 & 5 & 3 & 51 & 36 & 30 \\
\hline \multicolumn{7}{|r|}{} \\
\hline
\end{tabular}

MSM: Men having Sex with Men; IDU: Intravenous Drug Users; CSW: Commercial Sex Workers. 


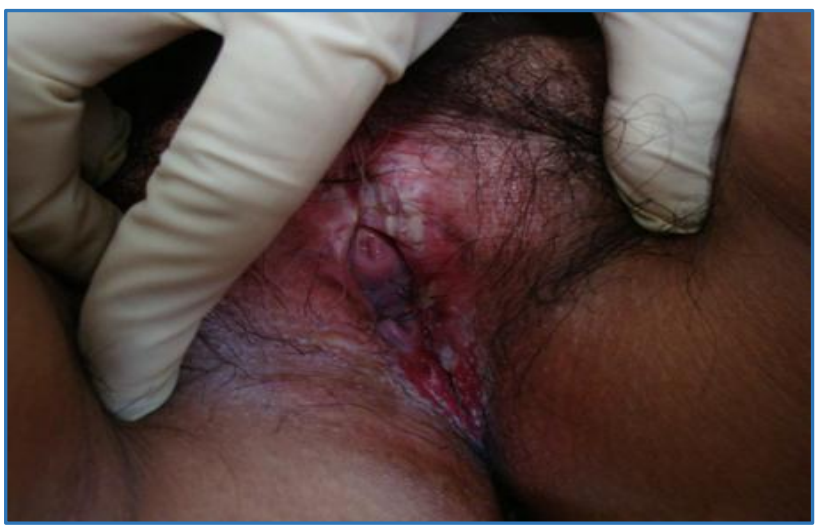

Picture 1: Vaginal Candidiasis

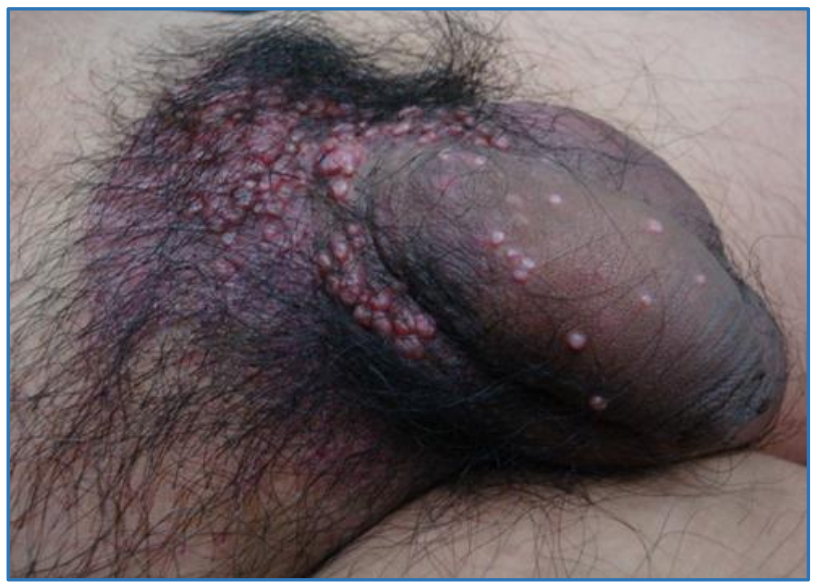

Picture 2: Molluscum Contagiosum

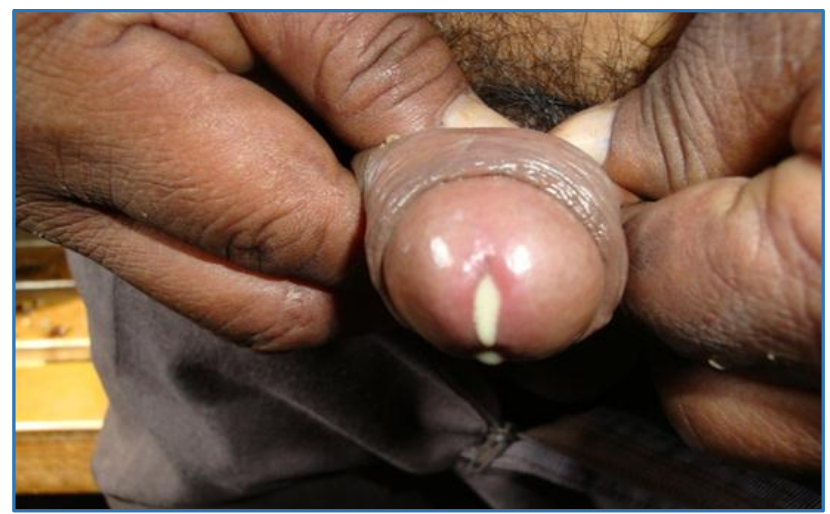

Picture 3: Gonorrhea

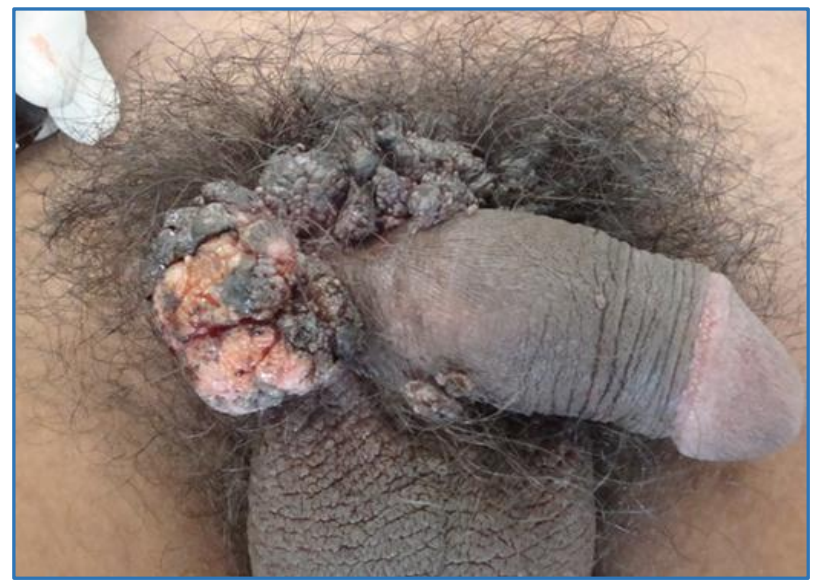

Picture 4: Genital Wart

\section{DISCUSSION}

In our study, STI accounted for $1.91 \%$ of the total patient who presented to the Outpatient Clinic under Dermatology Department. However, there is a slow increasing trend in the incidence over the study period. In a similar study conducted in another tertiary referral centre in Manipur done a decade back, an incidence of $3.30 \%$ of the total OPD attendance was noted.

The Male-to-Female ratio of patients who presented to the clinic was 1:3.6, which is in broad concordance with the study done by Patel $\mathrm{N}$ et $\mathrm{al}^{6}$ (1:2.4), but it is contrary to the study done by Nair TG et $\mathrm{al}^{7}$ and Arakkal et $\mathrm{al}^{8}$ where the male-tofemale ratio is $2: 1$. Such a high ratio in females is understandable from the fact that a major chunk of the patient fell under the category of vaginal candidiasis.

Maximum number of patients were noted in the sexually active group (25-50 years) followed by less than 25 years. This is consistent with the study done by Zamzachin et $\mathrm{al}^{9}$ Sen et $\mathrm{l}^{10}$ and Vora et al. ${ }^{11}$ This can be attributed to the fact that people are becoming sexually active at a younger age group and inadequate education on STIs for youths, may account for the sharp rise in STIs incidence amongst adolescent and younger age groups.

In the present study, the most common STD presentation was vaginal discharge (81.7\%). A study done by Desai et al ${ }^{1}$ in Surat among the female sex workers stated that only $12.7 \%$ complained of vaginal discharge; however, on further examination $51.7 \%$ were to have abnormal vaginal discharge. This is in broad concordance with the present study.

Vaginal discharge was followed by other STIs (like scabies, molluscum contagiosum) (14.5\%), genital wart (10.8\%), lower abdominal pain (3.46\%), herpetic-genital ulcer disease (1.88\%), urethral discharge (1.1\%), nonherpetic-genital ulcer disease $(1.4 \%)$ and inguinal bubo $(0.3 \%)$. This study shows an increase in the rate of genital wart, which is in concordance with the previous studies done in Manipur. An earlier study done in Manipur by Brajachand et $\mathrm{al}^{12}$ has shown balanoposthitis $(27.4 \%)$ to be the commonest STD followed by NGU (14.5\%) and genital warts (13.5\%). In Zamzachin et al study, the types of STD have been classified as ulcerative, discharge and miscellaneous groups. In the ulcerative group, the commonest STD was balanoposthitis (22\%) followed by chancroid (10.8\%), genital warts (9.6\%), syphilis (6.2\%), genital herpes (5.2\%), molluscum (0.9\%), granuloma inguinale $(0.6 \%)$ and lymphogranuloma venereum $(0.1 \%)$. Secondary syphilis $(52.2 \%)$ and primary syphilis $(38.8 \%)$ were the common presentations of syphilis. Gonorrhoea (11.8\%) was followed by NGU $(11.2 \%)$, vaginal candidiasis $(2.6 \%)$, trichomoniasis $(2.3 \%)$ and bacterial vaginosis $(0.6 \%)$ in the discharge group. STD related scabies and fungal infections accounted for $9.7 \%$ and psychosexual disorders were observed in $6.4 \%$ in the miscellaneous group. In Desai et al study, active syphilis rose from $18.5 \%$ in 1992 to $22.9 \%$ in 2000 . However, in the present study only $0.6 \%$ of the STD patients were of syphilis. The prevalence rate of gonorrhoea was higher in a study done in Kolkata (9.1\%),13 done among the high risk group in red light area. However, in the study done by Arakkal et al in 2013, the most common STI in males was candidal balanoposthitis, and in females was vaginal/cervical discharge (candidal) followed by viral infections like genital herpes and genital wart. 
In the present study out of those fresh cases with STDs HIV was positive in only 8 patients, whereas previous studies show a slightly higher rate. Both STD and HIV infections are associated with some high risk behaviour, that is sexual intercourse with multiple partners. According to the latest estimates, ${ }^{14}$ there are close to 2.4 million people living with HIV in India with an adult prevalence of $0.3 \%$. The prevalence of HIV is high in the 15-49 age group and accounts for $88.7 \%$ of all infections. More men are HIV positive than women. Nationally, the prevalence rate for adult females is $0.29 \%$, while for males it is $0.43 \%$. The mode of transmission of STI and HIV are same; presence of STI enhances the HIV acquisition and transmission risk by 4-10 times.

A survey of literature showed that during 1960s and 70s, bacterial infections like syphilis, chancroid and gonorrhoea were rampant and viral infections like genital herpes and condyloma acuminatum were rare. ${ }^{8}$ A retrospective data analysis from 1994 to 1998 at Medical College, Trivandrum showed that the commonest STD was syphilis, both in men and women followed by genital herpes and condyloma acuminate. ${ }^{8}$ In the present study an increase in the incidence of candidiasis and genital wart has been noted, while there is a decrease in the incidence of syphilis. Thus to conclude, sexually transmitted disease continues to be a major public health problem. Imparting health education, knowledge about safe sexual practice, early reporting to health facility are required to curb the incidence and reduce the spread.

\section{REFERENCES}

1. Desai VK, Kosambiya JK, Thakor HG, et al. Prevalence of sexually transmitted infections and performance of STI syndrome against aetiological diagnosis, in female sex workers of red light area in Surat, India. Sex Transm Infect 2003;79(2):111-5.

2. Adler M, Foster S, Grosskrurth. Sexual health and health care, sexually transmitted infections. Guidelines for prevention and treatment: health and population occasional paper DFID, London.

3. Nayyar A. Questions and answers on reproductive tract infections and sexually transmitted infections. Population council, UNFPA.
4. Plummer FA, Simonsen JN, Cameron DW, et al. Cofactors in male-female sexual transmission of human immunodificiency virustype 1. J Infect Dis 1991;163(2): 233-9.

5. DeVincenzi L. A longitudinal study on human immunodeficiency virus transmission by heterosexual partners. European study group on heterosexual transmission on HIV. N Eng J Med 1994;331(6):341-6.

6. Patel N, Pitroda $\mathrm{H}$, Rathod $\mathrm{Y}$, et al. Clinical and demographic trends in a sexually transmitted infection clinic in ahmedabad (2003-2012): an epidemiologic analysis. Int J Med Sci Public Health 2013;2(4):1077-80.

7. Nair TG, Asha LK, Leelakumari PV. An epidemiological study of sexually transmitted diseases. Indian J Dermatol Venereol Leprol 2000;66(2):69-72.

8. Arakkal GK, Damarla SV, Kasetty HK, et al. Changing trends in sexually transmitted infection (STI) clinic attendees-current scenario. Int J Med Sci Public Health 2014;3(10):1215-18.

9. Zamzachin G, Singh NB, Devi TB. STD trends in regional institute of medical sciences, Manipur. Indian J Dermatol Venereol Leprol 2003;69(2):151-3.

10. Sen P, Chio MTW, Tan HH, et al. Rising trends of STIs and HIV infection in Singapore. A review of epidemiology over the last 10 years (1994-2003). Ann Acad Med Singapore 2006;35(4):229-35.

11. Vora R, Anjaneyan G, Doctor C, et al. Clinicoepidemiological study of sexually transmitted infections in males at a rural-based tertiary care center. Indian J Sex Transm Dis 2011;32(2):86-9.

12. Singh BN, Zamzachin G, Singh LH. HIV infection among STD patients attending the RIMS hospital. J Med Soc 1998;12:4-6.

13. Thawani G, Bhatia VN, Jana S. Herpes, cytomegalovirus and other STDs in high risk group. Indian J Sex Transm Dis 1996;17:11-14.

14. National STI/RTI Control and Prevention Programme. NACP phase III India. Published by ministry of family and health welfare. Government of India. 